\title{
SyNTHESIS OF CONTROL Signal FOR HydRAULiC HEXAPOD
}

\author{
Vojtěch Klouček \\ Center of Engineering Research Development, VÚTS, a.s., Design of Machinery, \\ Svárovská 619, Liberec XI - Růžodol I, 46001 Liberec, Czech Republic \\ e-mail: vojtech.kloucek@vuts.cz
}

\begin{abstract}
The article describes the hexapod with six linear hydraulic motors and six degrees of freedom. The hexapod consists of a rigid base plate, movable platform and six linear hydraulic motors, which are joined to the base plate and the movable platform by ball joints. In the first part of the article hexapod kinematics is resolved by using matrix methods of investigation of spatial multibody systems. The hexapod is used for the laboratory vibration excitation equivalent to the vibration measured with accelerometers in the real part operation. The second part of the article describes the synthesis of the control signal from the values measured by accelerometers. The computation routines of the synthesis are programmed in Maple interface.
\end{abstract}

\section{Introduction}

The object of study is a laboratory hydraulic hexapod used for dynamic testing of mechanical components [1], [2] and subassemblies, e.g. car seats (Fig. 1). Dimensions of hexapod described herein are known from drawing documentation.
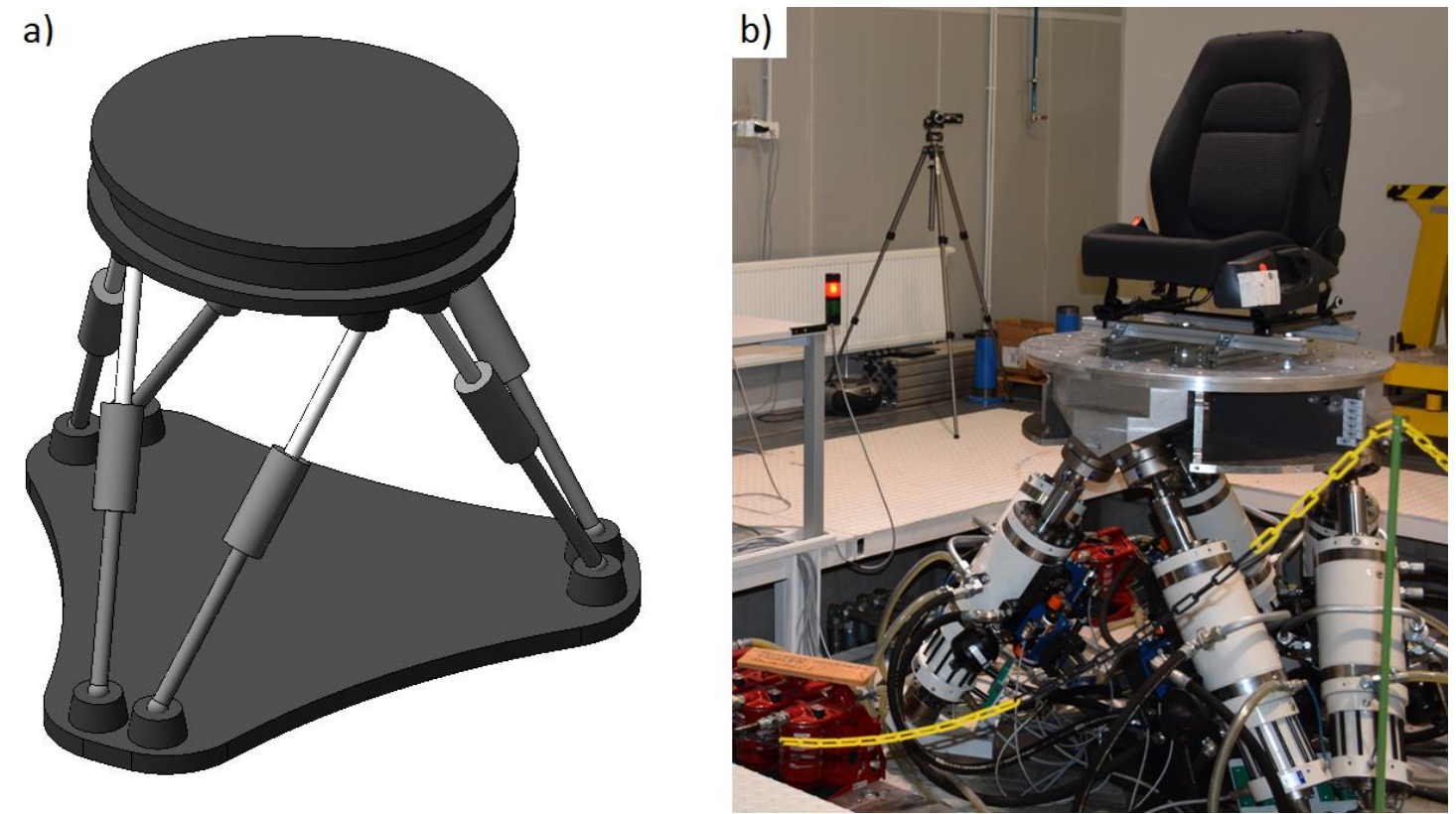

Source: a) Own using the CAD software, b) http://cxi.tul.cz/aktuality/aktualni-info-od-nas/B_Hexapod.JPG

Fig. 1: a) schematic CAD model of the hexapod, $b$ ) the hexapod with a car seat

The essence of the experiments performed on the hexapod is mounting an investigated object to the movable platform and excite the desired movement or vibration by hydraulic motors of the hexapod. Each experiment should simulate the real operation conditions of components as precisely as possible. Therefore the desired movement is measured in the real operation by accelerometers. 
Therefore the aim of the work is accelerometers' signals conversion to control signals for hydraulic motors of the hexapod. Since what is done is a processing of large amounts of measured data, it requires the conversion to be simple and fast.

\section{A description of the hexapod}

The hexapod consists of the base plate, movable platform and six hydraulic linear motors, which are joined to the base plate and platform by ball joints. The body of each hydraulic motor is fixed against a rotary motion around its longitudinal axis. The movable platform has six degrees of freedom towards the base plate [3]. There are two coordinate systems on the hexapod: Fixed ones $a: A x_{a} y_{a} z_{a}$ (rigid fixed with the base plate) and movable ones $b: B x_{b} y_{b} z_{b}$ (rigidly fixed with the movable platform). At a default position of the platform both of the coordinate systems coincide and are at the middle point of the platform's upper surface (Fig. 2).

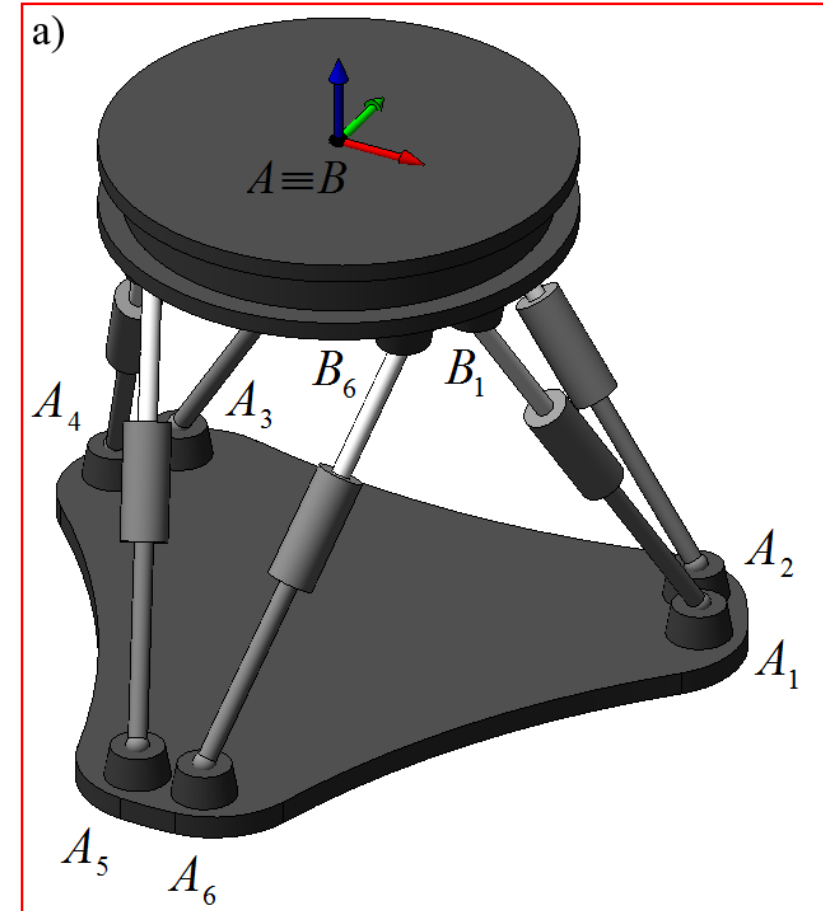

b)

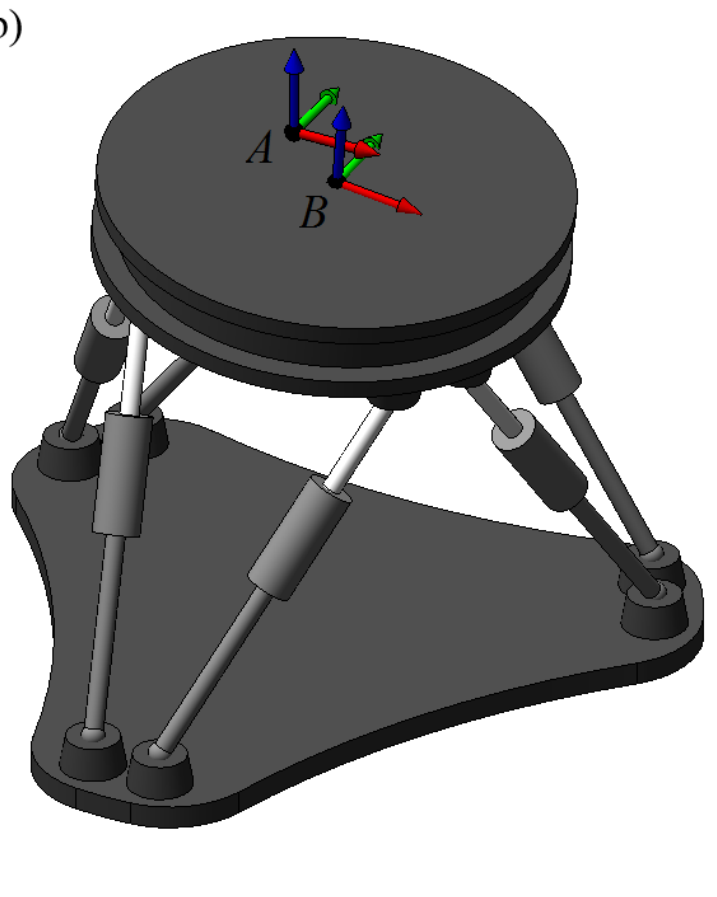

Source: Own using the CAD software

Fig. 2: a) hexapod at default position, b) hexapod at general position

\section{Coordinate systems transformation}

The hydro motors are numbered 1 to 6 , ball joints on the base plate $A_{1}$ to $A_{6}$, ball joints on the movable platform $B_{1}$ to $B_{6}$ (in Fig.1 only joints $B_{1}$ and $B_{6}$ ) are identified. Augmented radius vectors of the arbitrary point $Q$ in the coordinate systems $a$ and $b$ during motion $b: a$ are constrained by the transformation equation

$$
\mathbf{r}_{a Q}=\mathbf{T}_{a b} \mathbf{r}_{b Q},
$$

where $\mathbf{r}_{a Q}$ is the augmented position vector of point $Q$ in the coordinate system $a, \mathbf{r}_{b Q}$ is the augmented position vector of point $Q$ in the coordinate system $b$ and $\mathbf{T}_{a b}$ is a transformation matrix of motion $b: a$. 
Augmented radius vectors of joints $A_{i}, i=1 . .6$ in the coordinate system $a$ and joints $B_{i}, i=1 . .6$ in the coordinate system $b$ are known from the dimensions of the hexapod and they are

$$
\mathbf{r}_{a A i}=\left[\begin{array}{c}
\mathbf{u}_{a A i} \\
1
\end{array}\right], \quad \mathbf{r}_{b B i}=\left[\begin{array}{c}
\mathbf{u}_{b B i} \\
1
\end{array}\right], \quad \mathbf{u}_{a A i}=\left[x_{a A i}, y_{a A i}, z_{a A i}\right]^{T}, \quad \mathbf{u}_{b B i}=\left[x_{b B i}, y_{b B i}, z_{b B i}\right]^{T} .
$$

Transformation matrix during general motion $b: a$ is

$$
\mathbf{T}_{a b}=\left[\begin{array}{cc}
\mathbf{S}_{a b} & \mathbf{u}_{a b} \\
\mathbf{O} & 1
\end{array}\right], \quad \mathbf{S}_{a b}=\left[\begin{array}{lll}
a_{11} & a_{12} & a_{13} \\
a_{21} & a_{22} & a_{23} \\
a_{31} & a_{32} & a_{33}
\end{array}\right], \quad \mathbf{u}_{a b}=\left[\begin{array}{l}
a_{1} \\
a_{2} \\
a_{3}
\end{array}\right], \quad \mathbf{O}=[0,0,0],
$$

where $\mathbf{S}_{a b}$ is a directional cosines matrix and $\mathbf{u}_{a b}$ radius vector of point $B$ in the coordinate system $a$.

\section{$3 \quad$ Kinematic solution}

Each hydraulic motor has a default length $L_{0}$. The piston stroke of $i$-th hydraulic motor from the default position is $z_{i}$. The current length of the $i$-th hydraulic motor (distance of joints $A_{i}$ and $\left.B_{i}\right)$ is $L_{0}+z_{i}, i=1 . .6$.

There are six conditions for the current lengths of hydraulic motors in the arbitrary position [3] of the movable platform

$$
\left|\mathbf{u}_{a B i}-\mathbf{u}_{a A i}\right|=L_{0}+z_{i}, i=1 . .6
$$

Using a scalar product for determination of the vector length, it is possible to convert (4) to the equation

$$
\left(\mathbf{u}_{a B i}-\mathbf{u}_{a A i}\right)\left(\mathbf{u}_{a B i}-\mathbf{u}_{a A i}\right)=\left(L_{0}+z_{i}\right)^{2}, i=1 . .6
$$

It applies for the augmented radius vectors $B_{i}$ in the coordinate system $a$ the transformation equation (1)

$$
\mathbf{r}_{a B i}=\mathbf{T}_{a b} \mathbf{r}_{b B i}=\left[\begin{array}{c}
\mathbf{u}_{a B i} \\
1
\end{array}\right]=\left[\begin{array}{cc}
\mathbf{S}_{a b} & \mathbf{u}_{a b} \\
\mathbf{O} & 1
\end{array}\right]\left[\begin{array}{c}
\mathbf{u}_{b B i} \\
1
\end{array}\right]
$$

The physical meaning of variable $\left(L_{0}+z_{i}\right)$ (current length of $i$-th hydraulic motor) enforces a condition $L_{0}+z_{i}>0$. Since the left hand side of (5) is a sum of second powers, it holds that $\left(\mathbf{u}_{a B i}-\mathbf{u}_{a A i}\right) \cdot\left(\mathbf{u}_{a B i}-\mathbf{u}_{a A i}\right)>0$. The piston stroke of the $i$-th hydraulic motor therefore is

$$
z_{i}=\sqrt{\left(\mathbf{u}_{a B i}-\mathbf{u}_{a A i}\right)\left(\mathbf{u}_{a B i}-\mathbf{u}_{a A i}\right)}-L_{0} .
$$


If the transformation matrix components are known, solving of hydraulic motors' piston strokes is easy.

\section{Solving of transformation matrix components}

The task is based in such a way that it is necessary to compute the components of the transformation matrix from the measured signals of accelerometers (known radius vectors of $n$ points, where $n$ is the number of triaxial accelerometers used). Since accelerometers' signals are composed of the acceleration values in three mutually perpendicular directions, it is necessary first to convert these values to the position values.

Let there be a coordinate system in the space of the studied body so that after mounting the body to the hexapod movable platform the coordinate system coincides with the coordinate system $b$. Let there be $n$ triaxial accelerometers on the studied body so that the accelerometers' axes are parallel with the axes of the coordinate system $b$ and they do not lie on the straight line. The augmented radius vector of $j$-th accelerometer in the coordinate system $b$ is known and it is

$$
\mathbf{r}_{b M j}=\left[\begin{array}{c}
\mathbf{u}_{b M j} \\
1
\end{array}\right], \quad \mathbf{u}_{b M j}=\left[x_{b M j}, y_{b M j}, z_{b M j}\right]^{T}, \quad j=1 . . n .
$$

The coordinate systems $a$ and $b$ are chosen so that they coincide in the default position of the movable platform. Let the components of the converted signal of $j$-th accelerometer be $x_{j}, y_{j}, z_{j}$. The augmented radius vectors of the accelerometers in the coordinate system $a$ are

$$
\mathbf{r}_{a M j}=\left[\begin{array}{c}
\mathbf{u}_{a M j} \\
1
\end{array}\right], \quad \mathbf{u}_{a M j}=\left[x_{b M j}+x_{j}, y_{b M j}+y_{j}, z_{b M j}+z_{j}\right]^{T}, \quad j=1 . . n
$$

For the radius vectors of accelerometers the transformation equation (1) also applies, therefore

$$
\mathbf{r}_{a M j}=\mathbf{T}_{a b} \mathbf{r}_{b M j}, \quad j=1 . . n .
$$

\subsection{Solving transformation matrix components using three accelerometers}

The position of the body in the 3D space is definitely determined by the coordinates of its three points which do not lie in a straight line. Of these nine coordinates only six are independent because the assumption of a rigid body implies three conditions of constant mutual distances of these points.

When using three accelerometers, it is $n=3$. We have nine available signal components $x_{j}, y_{j}, z_{j}, j=1 . . n$. Of these only six components are independent, e.g. $x_{1}, y_{1}, z_{1}, y_{2}, z_{2}, z_{3}$. By using (10) we get a system of six linear equations for twelve unknown transformation matrix components $a_{i j}, a_{i}, i, j=1 . .3$ for each recorded time point.

Directional cosines matrix $\mathbf{S}_{a b}$ contains in columns the coordinates of unit directional vectors of the coordinate system's $b$ axes in the coordinate system $a$. Let we denote these vectors $\mathbf{b}_{x}, \mathbf{b}_{y}, \mathbf{b}_{z}$, where

$$
\mathbf{b}_{x}=\left[a_{11}, a_{21}, a_{31}\right]^{T}, \quad \mathbf{b}_{y}=\left[a_{12}, a_{22}, a_{32}\right]^{T}, \quad \mathbf{b}_{z}=\left[a_{13}, a_{23}, a_{33}\right]^{T} .
$$


Any two of these vectors have to be perpendicular and the length of each of them is 1 , which can be expressed by using scalar products

$$
\mathbf{b}_{x} \mathbf{b}_{y}=0, \quad \mathbf{b}_{y} \mathbf{b}_{z}=0, \quad \mathbf{b}_{z} \mathbf{b}_{x}=0, \quad \mathbf{b}_{x} \mathbf{b}_{x}=1, \quad \mathbf{b}_{y} \mathbf{b}_{y}=1, \quad \mathbf{b}_{z} \mathbf{b}_{z}=1 .
$$

For calculations of transformation matrix components it is necessary to solve the system of twelve equations for twelve unknowns. The equation system consists of six linear equations obtained from (10) and six non-linear equations (12).

The solution of this equation system is necessary to be done for each time point of the measured accelerometers' signals. As it is a system of non-linear equations, it is possible to solve it by using the appropriate iterative method. However, with the high number of the measured values, this task is time consuming and demanding on computer capacity.

\subsection{Solving transformation matrix components using four accelerometers}

When using four accelerometers, it is $n=4$. We have twelve available signal components $x_{j}, y_{j}, z_{j}, j=1 . . n$. Six of them are independent again. If we assume that the studied body is ideally rigid and accelerometers are ideally fixed to the body, the components of these signals comply with six conditions for the constant distances between the accelerometers. These six conditions are equivalent with the equations (12), because they represent the fact that the studied body is rigid and thus the movable coordinate system remains orthonormal.

If we substitute the measured values to equation (10) and if we use all twelve components of the accelerometer signals, we obtain a system of twelve linear equations for twelve unknown components of the transformation matrix (3).

We will write this system in a matrix form

$$
\mathbf{M}_{S} \mathbf{x}=\mathbf{p},
$$

where $\mathbf{M}_{S}$ is a matrix of the equation system (square, 12th order), $\mathbf{x}$ vector of unknowns, and $\mathbf{p}$ vector of right hand sides.

The matrix $\mathbf{M}_{S}$ contains components of vectors $\mathbf{u}_{b M j}$, vector $\mathbf{x}$ contains twelve unknown transformation matrix components, and vector $\mathbf{p}$ contains components of vectors $\mathbf{u}_{a M j}$.

The system (13) has just one solution if and only if the determinant of the matrix of equation system $D_{S}=\left|\mathbf{M}_{S}\right| \neq 0$. If this condition is accomplished, then the equation system is easy to solve, e.g. by using Gauss elimination or matrix inverse, because the matrix $\mathbf{M}_{S}$ contains many zero components.

It applies the theorem $D_{S} \neq 0$ if and only if the accelerometers 1 to 4 do not lie in a plane. We will prove this theorem. Let there be three vectors with the start point in the location of the accelerometer 1 and end points in the locations of the accelerometers 2, 3, 4. The components of these vectors will be put into columns of matrix $\mathbf{M}_{V}$, so that

$$
\mathbf{M}_{V}=\left[\mathbf{u}_{b M 2}-\mathbf{u}_{b M 1}, \mathbf{u}_{b M 3}-\mathbf{u}_{b M 1}, \mathbf{u}_{b M 4}-\mathbf{u}_{b M 1}\right]
$$


Determinant of matrix $\mathbf{M}_{V}$ we denote $D_{V}=\left|\mathbf{M}_{V}\right|$. By direct calculation of the determinants $D_{S}$ and $D_{V}$ it is possible to verify the equality

$$
D_{S}=D_{V}^{3}
$$

The condition $D_{S} \neq 0$ is true if and only if the determinant $D_{V} \neq 0$, which results from the equality (15). A determinant is nonzero if and only if all its columns are linearly independent, which occurs only if the accelerometers 1 to 4 do not lie on a plane. This condition is necessary and sufficient. The proof is finished.

\section{Conclusion}

In this paper we explored kinematics of the hydraulic hexapod with six degrees of freedom. Furthermore, the method of conversion of the transformation matrix components to strokes of hexapod hydraulic motors was proposed. For a simulation of motion, measured in a real operation using accelerometers, it is necessary to convert the measured data to the transformation matrix components at each time. There are two methods deduced: When using three accelerometers and when using four accelerometers. It was mathematically deduced that while using four accelerometers, the conversion is significantly faster and easier.

\section{Acknowledgements}

The research was made possible by VÚTS, a.s., research project NPU - L012, 99253/5 and Technical university of Liberec, Faculty of Mechanical Engineering, Department of the Design of Machine Elements and Mechanism.

\section{Literature}

[1] PETŘÍK, J.; MARTONKA, R.: Measuring platform for seat testing. Proceedings of the $52^{\text {th }}$ International Conference of Machine Design Departments. pp. 184-187, ISBN 97880-248-2450-5. Š Technical University of Ostrava, 2011.

[2] FLIEGEL, V.; MARTONKA, R.: Electro-dynamic measuring equipment. Proceedings of the Conference MMa MS. pp. 101-103, ISBN 978-80-553-0731-2. Technical University of Košice, 2011.

[3] FLIEGEL, V.; MARTONKA, R.: Hexapod-the Platform with 6DOF. Proceedings of the $54^{\text {th }}$ International Conference of Machine Design Departments. pp. 111-116, ISBN 978-80-7372-986-8. Technical University of Liberec, 2013.

Ing. Vojtěch Klouček, Ph.D. 


\section{SYNTÉZA ŘIIDICÍHO SIGNÁLU PRO HYDRAULICKÝ HEXAPOD}

Článek popisuje hexapod se šesti lineárními hydromotory a šesti stupni volnosti. Tento hexapod se skládá z tuhé základní desky, pohyblivé plošiny a šesti lineárních hydromotorů, které jsou připojeny $\mathrm{k}$ základní desce a pohyblivé plošině pomocí kulových čepů. V první části článku je řešena kinematika hexapodu za využití maticových metod zkoumání prostorových vázaných mechanických systémů. Hexapod je používán pro laboratorní vybuzení vibrací, které jsou ekvivalentní vibracím naměřeným pomocí akcelerometrů v reálném provozu. Druhá část článku popisuje syntézu řídicího signálu z hodnot naměřených akcelerometry. Výpočtové algoritmy syntézy jsou naprogramovány $\mathrm{v}$ prostředí software Maple.

\section{SYNTHESE DES STEUERSIGNALS FÜR EINEN HYDRAULISCHEN HEXAPOD}

Dieser Artikel beschreibt eine Hexapod-Einrichtung mit sechs Linearmotoren und sechs Freiheitsgraden. Der Hexapod besteht aus einer starren Grundplatte, einer beweglichen Plattform und sechs linearen otoren, die mit der Grundplatte und der mobilen Plattform mittels Kugelbolzen verbunden sind. Im ersten Teil des Artikels wird die Kinematik des Hexapods mit Hilfe von Matrix-Methoden zur Untersuchung von Mehrkörpersystemen untersucht. Der Hexapod wird im Labor zur Anregung von Schwingungen genutzt, die äquivalent $\mathrm{zu}$ den im realen Betrieb mit Hilfe des Beschleunigungsmessers gemessenen Vibrationen sind. Der zweite Teil des Textes beschreibt die Synthese des Steuersignals aus den von Beschleunigungsmessern gemessenen Werten. Die Synthese-Algorithmen sind in Software Maple programmiert.

\section{SYNTEZA SYGNAŁU STEROWANIA DLA HYDRAULICZNEGO SZEŚCIONOGA}

Artykuł opisuje sześcionóg z sześcioma liniowymi silnikami hydraulicznymi i sześcioma stopniami swobody. Sześcionóg składa się ze sztywnej płyty głównej, ruchomej platformy i sześciu liniowych silników hydraulicznych, które są połączone z płytą główną i ruchomą platformą za pomocą sworzni kulistych. W pierwszej części artykułu przedstawiono kinematykę sześcionoga stosując macierzowe metody badania przestrzennych mechanicznych systemów wieloobiektowych. Sześcionóg wykorzystywany jest do laboratoryjnego wywoływania drgań, które odpowiadają wibracjom namierzonym przy pomocy akcelerometrów w rzeczywistym świecie. Druga część artykułu opisuje syntezę sygnału sterującego z wartości namierzonych przez akcelerometry. Algorytmy obliczeniowe syntezy zaprogramowano w oprogramowaniu Maple. 